\title{
The Ideological Asymmetry of the American Party System
}

\author{
YPHTACH LELKES AND PAUL M. SNIDERMAN*
}

\begin{abstract}
Most Americans support liberal policies on the social welfare agenda, the dominant policy cleavage in American politics. Yet a striking feature of the US party system is its tendency to equilibrium. How, then, does the Republican Party minimize defection on the social welfare agenda? The results of this study illustrate a deep ideological asymmetry between the parties. Republican identifiers are ideologically aware and oriented to a degree that far exceeds their Democratic counterparts. Our investigation, which utilizes cross-sectional, longitudinal and experimental data, demonstrates the role of ideological awareness and involvement in the Republicans' ability to maintain the backing of their supporters even on issues on which the position of the Democratic Party is widely popular. It also exposes two mechanisms, party branding and the use of the status quo as a focal point, that Democrats use to retain or rally support for issues on the social welfare agenda on which the Republican Party's position is widely popular.
\end{abstract}

\section{THE IDEOLOGICAL ASYMMETRY OF THE AMERICAN PARTY SYSTEM}

For a half-century or more, the positions of the Democratic Party on the dominant electoral agenda in American politics have been far more popular than those of the Republican Party. ${ }^{1}$ How, we ask, has the Republican Party induced its supporters to continue to oppose policies that are not only widely popular in the electorate as a whole, but from which many of them would benefit?

The answer to this question, our results indicate, calls attention to a neglected feature of the contemporary US party system: the ideological asymmetry between the two parties. Republican identifiers, we show, are ideologically aware and oriented to a degree that far exceeds their Democratic counterparts. Their identification with the ideological outlook of their party indeed, their appreciation of their party as a proponent of an ideological outlook - helps fortify their opposition even to widely popular social welfare policies.

The objective of this twofold study is threefold. The first is to test the hypothesis of partisan asymmetry in ideological awareness and orientation. The second objective is to explicitly evaluate counter-hypotheses. The most compelling counter-hypothesis, in our judgment, is self-interest. Republican supporters, it may reasonably be argued, oppose increases in government spending for social welfare programs not because of ideological conservatism, but out of a concern that the spending increases will come from their pockets in higher taxes. The third objective follows from results confirming that Republicans are strikingly more likely than Democrats to be ideologically aware and engaged. How, then, does the Democratic

\footnotetext{
* Amsterdam School of Communication Research, University of Amsterdam (email: y.lelkes@uva.nl); Department of Political Science, Stanford University (email: paulms@stanford.edu). We thank Kevin Arceneaux, Justin Grimmer, John Sides, Gaurav Sood and Christopher Wlezien for helpful advice and encouragement. Data replication sets and online appendices are available at http://dx.doi.org/doi:10.1017/ S0007123414000404.

1 E.g., Ellis and Stimson 2012; Stimson 2004.
} 
Party hold onto its supporters on those issues on the social welfare agenda (for example, food stamps) on which its position is the unpopular one? This study evaluates two mechanisms in particular: party branding and the use of the status quo as a focal point.

We proceed in three steps. First, we detail our hypotheses; secondly, we put them to a series of tests using an array of datasets and modes of analysis, including time series and survey experiments; thirdly, we draw out some broader implications of our findings for the study of ideology and the American party system.

\section{HYPOTHESES}

The study of ideology has typically been the study of the political ideas (or lack thereof) in the electorate all in all. Differences among citizens' degree of political engagement and sophistication have been recognized from the start, to be sure. But from the beginning, the object of study has been ideology in the mass public. ${ }^{2}$ Our aim is to embed the study of ideology in the party system.

Political parties organize governments, frame policy alternatives and provide the main gateway to public office. While they periodically answer to the electorate via the ballot box, all they need to do is secure a vote. More importantly, parties must answer to their supporters during and between elections, and secure their involvement well beyond the vote. It follows indeed, it is well established - that partisans are more engaged in politics, up to the mark and better informed in their political thinking than ordinary citizens. But it does not follow that supporters of every party are equally politically engaged, equally ideologically aware and equally oriented to policy programmatic considerations. On the contrary, this study tests the hypothesis that supporters of the Republican Party are far more ideologically aware and oriented than their Democratic counterparts.

We call this the Ideological Asymmetry Hypothesis. Its basis is the convergence of three lines of research. First, in their pioneering study, Feldman and Zaller advance a theoretical rationale for ideological asymmetry - the greater consonance of the values of conservatism and the American ethos - and present suggestive results showing the greater consistency of policy choices and reasons in favor of them among conservatives. ${ }^{3}$ Secondly, focusing on the parties at the elite level, Freeman and Heaney et al. respectively make strong arguments that the Democratic Party is more 'pluralistic and polycentric' (p. 339), while the Republican Party is more internally coherent and hierarchically organized at the elite level. ${ }^{4}$ Thirdly, Abramowitz and Saunders, and Levendusky, have called attention to the fact that Republicans are markedly more likely than Democrats to identify with the ideological outlook of their party. ${ }^{5}$ To be sure, it does not necessarily follow that Republicans are more likely to identify with the policy positions of their party issue by issue. Indeed, based on the evidence at hand, Democrats are more of one mind on many issues, including most on the social welfare agenda. ${ }^{6}$ The hypothesis of this study is that the greater ideological awareness of Republican identifiers helps the Republican Party retain their backing on issues on which it has committed itself to broadly unpopular positions.

To motivate our larger argument about ideological asymmetry between the parties, we address a puzzle in American politics. The social welfare (or scope-of-government) agenda is

${ }^{2}$ E.g., Converse 1964; Kinder 1983.

${ }^{3}$ Feldman and Zaller 1992.

${ }^{4}$ Freeman 1986, 339; Heaney et al. 2012.

5 Abramowitz and Saunders 1998; Levendusky 2009.

${ }^{6}$ See Levendusky (2009) for the most detailed examination of variation in sorting by policy. 
the dominant cleavage in contemporary American politics. ${ }^{7}$ There are cyclical swings in the popularity of increasing (and decreasing) the scope of government, and at any given political juncture, each party has specific issues bearing on the scope of government on which their position is the more popular. Over the longest period of time, however, the liberal position has been more popular, often far more popular, than the conservative position on most issues on the social welfare agenda. ${ }^{8}$ For example, according to the 2004 American National Election Study (ANES), 76 per cent of Americans would like to increase federal spending on public schools and 62 per cent support increasing spending on social security. It is easier for the Democratic Party to secure the backing of its supporters on most social welfare policies. By contrast, on most issues on the social welfare agenda, the Republican Party is swimming upstream.

How, then, does the Republican Party maintain the backing of its supporters for policies that are widely unpopular in the electorate - and from which many of them would manifestly benefit? Broadly stated, the Ideological Asymmetry Hypothesis suggests an answer. Republicans, to a striking degree, are more ideologically aware and oriented than Democrats, and the ideologically oriented politics of Republicans helps hold them in place when their party takes stands against widely popular policies. More specifically:

HYPOTHESIS 1: To a degree that sets them distinctly apart from Democratic identifiers, Republican identifiers will know that theirs is the party of conservatism; that they will identify with the conservative outlook that their party is identified with; and that they will base their evaluations of their party, again to a distinctively greater degree than Democrats, on its role as a spokesman for a programmatic approach to politics.

The first hypothesis entails a prediction of Republican ideological solidarity. Our second hypothesis picks out a policy classification mechanism. From its inception, the social welfare agenda has been underpinned by a principle of universalism. ${ }^{9}$ Policies vary in the degree to which they lend themselves to being characterized as benefiting society as a whole or only particular groups. Social security is a paradigmatically universalistic policy, welfare a paradigmatically particularistic one. ${ }^{10}$ But a hallmark of liberalism is a disposition to categorize policies on the social welfare agenda as benefiting society as a whole. Conversely, a hallmark of conservatism is a disposition to categorize them as benefiting particular groups rather than society as a whole. Hence our second hypothesis:

HYPOTHESIS 2: Because Republicans tend overwhelmingly to identify with a conservative outlook on politics, and because conservatism favors a view of social welfare policies as benefiting particular groups rather than society as a whole, defection from the positions of their party is minimized on issues on the social welfare agenda.

Our third hypothesis addresses the ideological asymmetry of the American party system from the perspective of the Democratic Party. If its adherents are less ideological in their conception

\footnotetext{
7 See, for example, the seminal study of Ansolabehere, Snyder and Stewart (2001) for evidence that this cleavage, far from being narrowed or pushed aside in recent decades, has become deeper still. See also Brown 1995; Carmines and Stimson 1990.

${ }^{8}$ Ellis and Stimson 2009, 2011, 2012; Stimson 1991, 2004.

9 Petersen 2011; Petersen et al. 2012; Skocpol 1991; Wilson 1980.

10 Somewhat challengingly, the full expression is 'targeted within universalism', since benefits at any particular moment in time are awarded to a subset.
} 
of politics than their Republican counterparts, how does the Democratic Party retain or rally their support on those social welfare issues (for example, food stamps) on which its position is the broadly unpopular one?

HYPOTHESIS 3: Democrats will tend to retain or rally support on social welfare positions on which their position is broadly unpopular through 'Thinking Fast' type mechanisms: ${ }^{11}$ in particular, party branding ${ }^{12}$ and the use of the status quo as a focal point. ${ }^{13}$

\section{EMPIRICAL RESULTS}

It is standardly presumed that the meaning of party identification is the same for both parties. As Bartels has argued:

the impact of each level of partisan attachment is assumed here to be identical for Democratic and Republicans. This constraint seems to be desirable on theoretical grounds, since there is no a priori reason to expect the same expressed level of attachment to have different electoral consequences for one or the other party's partisans'. ${ }^{14}$

Bartels is speaking here of the symmetry of the degrees of strength of attachment to a party: A 'weak' Democratic identifier is attached to her party with the same - or very similar - degree of strength as a 'weak' Republican identifier. As far as giving an account of voting, a presumption of party symmetry in the strength of identification seems a close enough approximation. Synonymy of meaning is another matter. ${ }^{15}$

\section{Ideological Asymmetry between the Parties}

Our overarching hypothesis is that Republicans take ideological considerations into account to a strikingly greater degree than Democrats. If this is true, what else must be true? Minimally, Republicans must be markedly more likely than Democrats to identify with the ideological outlook with which their party is identified. Republicans must also be markedly more likely than Democrats to understand the ideological logic of the party system; that is, to understand that the Republican Party is the conservative party, and the Democratic Party is the liberal party. Finally, Republicans must not merely be more cognizant of the ideological orientation of their party, but also be more likely to base their evaluation of their party on ideological or programmatic considerations. To the extent that Republican identifiers are decisively more likely than Democrats to meet these conditions, an assumption of the synonymy of the meaning of party identification should be rejected.

Figure 1 presents results addressing all three conditions - sorting, knowledge of the ideological reputations of the parties and active use of ideological/policy considerations in evaluating the parties - for Republican and Democratic identifiers, separately. ${ }^{16}$ The solid lines track the proportion of Democratic partisans; the dotted lines those of Republicans. The data,

11 Kahneman 2011.

12 E.g., Bullock 2011; Dalton, Beck, and Huckfeldt 1998; Kam 2005; Mondak 1993; Rahn 1993; Squire and Smith 1988.

13 Kahneman 2011.

14 Bartels 2000, 39, ft. 7.

15 For an earlier and conceptually more radical approach to the problem of ideological synonymy of meaning on the research agenda, see Conover and Feldman (1981).

16 All analyses are weighted to be representative of the population. 
(a)

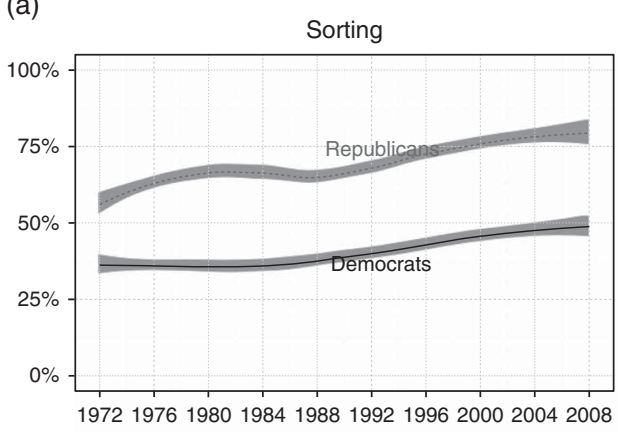

(c)

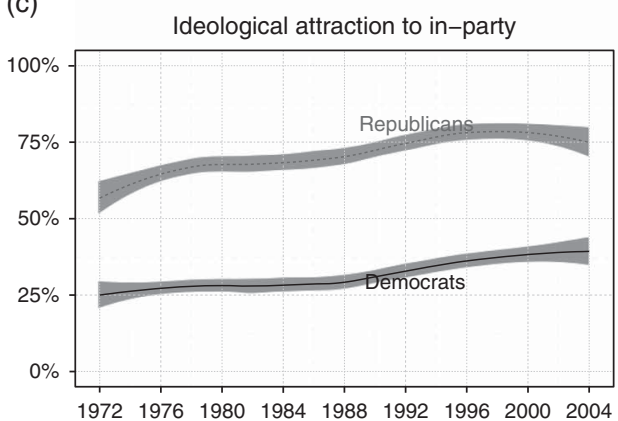

(b)

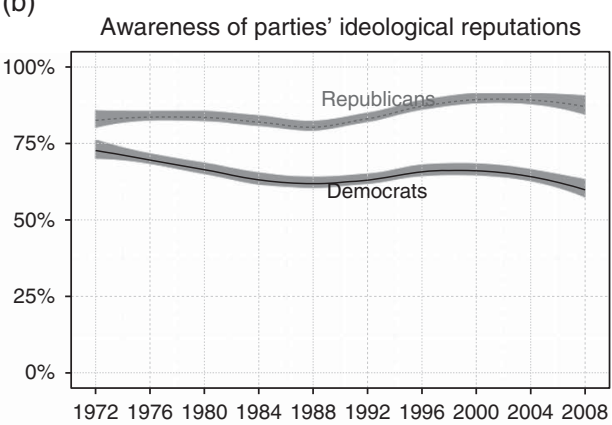

(d)

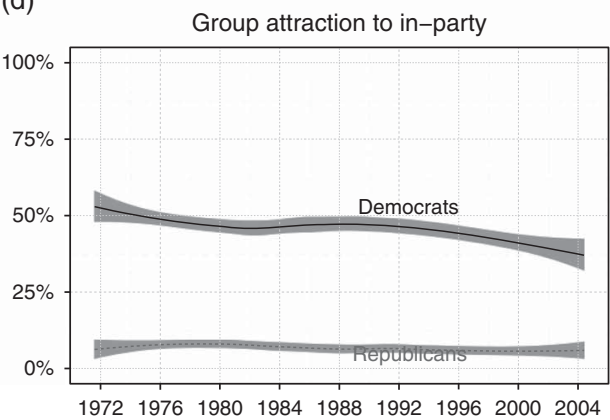

Fig. 1. Indicators of ideologically grounded reasoning by party and over time

which are smoothed over individuals and years, come from the 1972-2008 ANES cumulative data file.

Although both Republicans and Democrats are markedly more likely to be sorted today than forty years ago, Republicans are markedly more likely to identify as conservatives than Democrats are to identify as liberals (Panel A). This gap has remained remarkably stable over time - a Republican identifier is roughly 30 per cent more likely than a Democratic one to be sorted.

Panel B of Figure 1 reports the proportion that knows the ideological reputations of the two parties. ${ }^{17}$ The results in this panel are virtually identical to those in Panel A. The proportion of Republican identifiers that knows the parties' ideological reputation is dramatically higher than that of their Democratic counterparts. If anything, this difference has increased over time, from a difference in 10 per cent or so in the 1970s, to more than twice that today.

Panel C of Figure 1 reports the proportions of partisans that give ideological/policy grounded reasons for liking their political party, again stratified by party identification. ${ }^{18}$ The results are even more striking in this panel than in the upper and middle panels. Quite simply, the

17 The measure of knowledge of the parties' ideological reputations is the standard ANES measure: respondents are asked 'Where would you place the [Democratic Party/Republican Party]?' and then given the seven-point liberal-conservative measure. Respondents who said the Democratic Party was more liberal than the Republican Party were considered knowledgeable.

${ }^{18}$ Respondents were asked 'Is there anything in particular that you like about the [Democratic party/ Republican party]? What is that?' The ANES collapsed these open-ended comments into twelve different categories. We considered the following reasons to be ideological in nature: government management, government activity/philosophy, domestic policies, foreign policies. 
proportion of Republicans giving ideological reasons for liking their party outnumbers the proportion of Democrats giving similar reasons by a margin of two to one.

If only a minority of Democrats is bound to their party for ideological reasons, what is the majority thinking of when they think of themselves as 'Democrats'? The answer is revealed in Panel D of Figure 1, which plots the proportion that likes their party because of its connections to various social groups. ${ }^{19}$ Consistent with Green, Palmquist and Schickler, ${ }^{20}$ Democrats refer at least as often to the party's constituent social groups as its ideological underpinnings. In contrast, the percentage of Republicans that likes their party for its relationship to social groups barely reaches double digits.

These results bring into sharp focus the depth of the ideological asymmetry in the American party system. Republicans are, and have been for at least forty years, in another league than Democrats. Politically sophisticated Republicans far outpoint their Democratic counterparts in terms of: (1) the likelihood that they are ideologically sorted; (2) their understanding of the ideological structure of the party system; and (3) their readiness to use ideological considerations to explain why they like their party. ${ }^{21}$

Of course, it can be argued that the asymmetry between the two parties has little or nothing to do with the parties themselves. It may instead be a product of long-standing socio-economic differences between the parties. For instance, Democrats tend to draw support from more disadvantaged groups than do Republicans and, according the ANES data, over the past forty years, 17 per cent of Democrats hold a college degree compared to 28 per cent of Republicans. The Republican coalition has also been consistently smaller than the Democratic coalition. Since the New Deal, the number of citizens identifying as Democrats has outnumbered those identifying as Republicans, sometimes at a rate of almost two to one. The differences between parties could simply be due to this imbalance in coalition size: it is easier to hold together a smaller coalition than a larger and more diverse one. ${ }^{22}$

To explore these potential confounds, we document the asymmetry in two more ways. As the size of the Republican coalition has edged closer to that of the Democratic coalition over time, we focus on three years in which the party identification imbalance varies. In 1980, roughly 19 per cent more ANES respondents identified as Democrats than Republicans. By 1996, this gap narrowed to 11 per cent, and by 2004, only a 3 per cent gap remained. If the asymmetry is due simply to differences in coalition size, the relationship between party identity and ideologically grounded reasoning should be weaker in 2004 than 1996, and weaker still than in 1980. Additionally, if the asymmetry is due to the social diversity of party coalitions, then any effect of party identity on ideologically grounded reasoning should evaporate with the imposition of demographic controls.

Figure 2 documents the relationship between ideologically grounded reasoning and party identity in each of the three years. Here we operationalize the dependent variable as the sum of

19 The collapsed open-ended measure is used for this panel as well, with the category 'Group Connections' coded as 1, and 0 otherwise. ANES coded responses such as 'White Collar-Workers', 'African Americans', 'Labor', 'Small Business', etc. as indicative of 'Group Connections'.

${ }^{20}$ We are, of course, aware that Green, Palmquist and Schickler (2002) advance their conceptualization of party identification as a social identity for both parties, but we cannot forbear pointing to evidence consistent with their conceptualization, even if it does not fully support it.

21 This observation has a far-reaching implication: standard 'controls' for political knowledge or sophistication underestimate the level of sophistication of ostensibly less sophisticated or less knowledgeable Republicans.

${ }^{22}$ Assume arguendo that social or contextual factors account for the differences in levels of ideological awareness between Republicans and Democrats. This would in no way diminish the significance for politics of these differences in ideological awareness. 


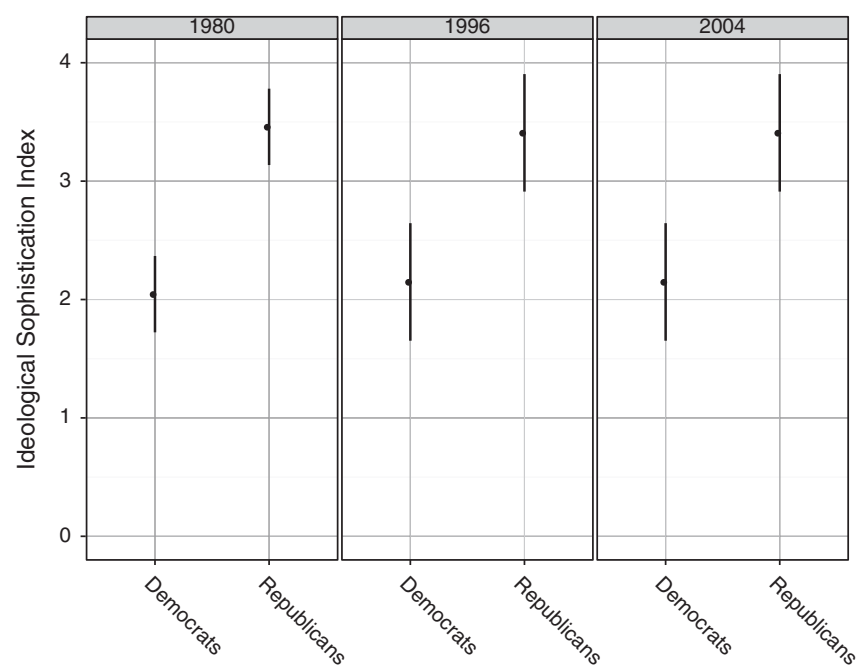

Fig. 2. Ideological sophistication between matched partisans

the individual indicators of ideologically grounded reasoning (sorting, awareness of reputation, ideological attraction and group attraction (reverse scored)). ${ }^{23}$ In each year, we utilize coarsened exact matching ${ }^{24}$ to ensure that Democrats and Republicans are balanced across a set of covariates that distinguishes them, including socio-economic status, race and indicators of political attentiveness. In each of the three years, Republicans scored higher on average roughly three-quarters of a point on a four-point scale - than Democrats on the Ideological Awareness Index. ${ }^{25}$ The apparent secular trend toward a closing gap is an artifact of the years we chose in this analysis - in 2002 the difference between Republicans and Democrats was the same size as in 1980; in 1972 the difference was the same as in $2004 .^{26}$

The asymmetry in ideological awareness between Republicans and Democrats is a matter of degree: it is not as though one party is ideologically committed and sophisticated and the other is not. But to appreciate the potential political import of this asymmetry, it is important to have at least an approximate sense of its magnitude. Accordingly, we again utilize the Ideological Awareness Index. Then, following Zaller and Bartels, ${ }^{27}$ we employ interviewers' assessments of respondents' knowledge of politics as a measure of ideological sophistication to illustrate

${ }^{23}$ We sum the indicators for economy of presentation. The results are similar for each indicator analyzed separately.

24 Iaccus, King, and Porro 2010.

25 As not all indicators are available for 2008, at the time of writing, the x-axis stops at 2004.

26 We achieve substantively similar results if we regress ideological awareness scores on these covariates (See Table A1). These results are not substantively different if we treat the index as categorical and utilize an ordered logit model, or if we decompose the index and predict its component parts.

27 The measure of political sophistication is interviewers' assessments of respondents' general knowledge about politics and public affairs. In using this measure, we are following a standard practice established by Zaller (1986, 1992) and Bartels (1996). An additional reason for deploying interviewer assessment of knowledge is that it is the only relevant measure used consistently in the ANES since 1972. Interviewers are asked to assess respondents' general level of information about politics and public affairs. Five response categories are provided: very high, fairly high, average, fairly low and very low. We have classified very and fairly high together as 'highly informed', and the remainder as 'less informed'. 


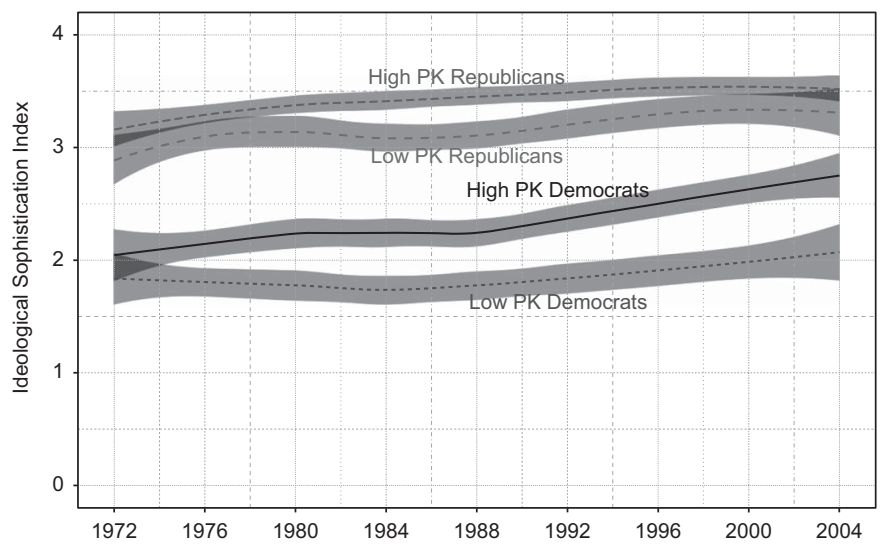

Fig. 3. Ideological sophistication by party, political knowledge (PK) and over time

how striking the difference in ideological awareness is between the parties over the last four decades.

These results, which can be seen in Figure 3, provide perhaps the clearest evidence of an ideological asymmetry. The level of ideological sophistication is, and has been for at least forty years, higher for less politically aware Republicans than it is for highly aware Democrats. In 2004, the mean ideological sophistication score for Republican respondents rated as more informed was 3.5; for more-informed Democrats the ideological sophistication score was only 2.77, and less-informed Democrats were far less ideologically sophisticated (2.07) than lessinformed Republicans (3.26). The evidence is clear: ideological sophistication is tied to being a Republican to a markedly greater degree than to being a Democrat.

\section{Uphill Issues for Republicans and Ideological Awareness}

The liberal position on most issues that make up the social welfare agenda, Stimson and his colleagues have shown, is more popular than the conservative position. All in all, the social welfare agenda thus favors the Democratic Party. ${ }^{28}$ To index ideological awareness, we rely on the 2012 ANES and form an additive measure combining knowledge of the ideological logic of the party system, classifying oneself into the ideological category matching one's party, knowledge of political figures and institutions $(\alpha=0.71)$.

Hypothesis 2: predicts that Republicans who are ideologically aware will distinctively resist the strong appeal of increasing support for core social welfare policies - including social security and childcare. Table 1 summarizes the mean scores of Republicans and Democrats, divided into high and low scorers on the index of ideological awareness (based on a median split), on a selection from the large number of easy ${ }^{29}$ issues for Democrats, garnered from the 2012 ANES. $^{30}$

${ }^{28}$ Stimson and colleagues do not explicitly draw this conclusion. Our result builds on theirs by placing the politics of the social welfare agenda in the context of the party system.

${ }_{29}$ Our usage of 'easy' and 'hard' issues differs from Carmines and Stimson's. For them, easy and hard turns on the cognitive demands of policies; for us, it is based on their popularity.

${ }^{30}$ The labels for these variables in the 2012 ANES, in the order they appear in Table 1, are fedspend_ss, fedspend_schools, fedspend_child, cses_exphlth, cses_expunemp and fedspend_poor. Spending preferences are coded so that 0 indicates 'cut spending', 0.5 'keep about the same' and 1 'increase spending'. 
тав Le $1 \quad$ Spending Preferences on Republicans' Uphill Issues

\begin{tabular}{|c|c|c|c|c|}
\hline & \multicolumn{2}{|c|}{ Democrats } & \multicolumn{2}{|c|}{ Republicans } \\
\hline & Low & High & Low & High \\
\hline Social Security & $\begin{array}{c}0.81 \\
(0.01)\end{array}$ & $\begin{array}{c}0.73 \\
(0.01)\end{array}$ & $\begin{array}{c}0.72 \\
(0.02)\end{array}$ & $\begin{array}{c}0.59 \\
(0.01)\end{array}$ \\
\hline Public Schools & $\begin{array}{c}0.88 \\
(0.01)\end{array}$ & $\begin{array}{c}0.90 \\
(0.01)\end{array}$ & $\begin{array}{c}0.78 \\
(0.01)\end{array}$ & $\begin{array}{c}0.56 \\
(0.01)\end{array}$ \\
\hline Child Care & $\begin{array}{c}0.69 \\
(0.01)\end{array}$ & $\begin{array}{c}0.67 \\
(0.01)\end{array}$ & $\begin{array}{c}0.52 \\
(0.02)\end{array}$ & $\begin{array}{c}0.34 \\
(0.01)\end{array}$ \\
\hline Unemployment & $\begin{array}{c}0.74 \\
(0.01)\end{array}$ & $\begin{array}{c}0.71 \\
(0.01)\end{array}$ & $\begin{array}{c}0.51 \\
(0.02)\end{array}$ & $\begin{array}{c}0.33 \\
(0.01)\end{array}$ \\
\hline Healthcare & $\begin{array}{c}0.57 \\
(0.01)\end{array}$ & $\begin{array}{c}0.56 \\
(0.01)\end{array}$ & $\begin{array}{c}0.44 \\
(0.01)\end{array}$ & $\begin{array}{c}0.31 \\
(0.01)\end{array}$ \\
\hline Poor People & $\begin{array}{c}0.59 \\
(0.01)\end{array}$ & $\begin{array}{c}0.67 \\
(0.01)\end{array}$ & $\begin{array}{c}0.53 \\
(0.01)\end{array}$ & $\begin{array}{c}0.37 \\
(0.01)\end{array}$ \\
\hline
\end{tabular}

For Democrats, a wide-gauge ideological orientation is hardly required to see the appeal of increasing government support for social security, public schools, child care and the like. On two issues, high-awareness and low-awareness Democrats are more than two digits apart, but on average, there is only a 0.04-point difference between the two Democratic groups, and both groups take the liberal position 100 per cent of the time.

Ideological awareness, by contrast, counts for Republicans. Republicans who display low levels of ideological awareness are much farther from their co-partisans than are high-awareness Democrats from their co-partisans. In fact, in many instances, low-awareness Republicans are closer to Democrats than to high-awareness Republicans (for example, on social security and public schools). By contrast, even for the most popular social policies (social security and public schools), ideologically aware Republicans resist increasing spending, and for other nearly as popular policies (unemployment, health care, child care and poverty programs) they decisively support cutting government spending. For Republicans, the mean difference in policy positions between the groups was 0.17 - four times larger than for their Democratic counterparts.

\section{Uphill Issues for Democrats and the Status Quo as a Focal Point}

Notwithstanding the Democratic Party's broad advantage on the social welfare agenda, the Republican Party's position on some issues is more popular. While it is a smaller number of issues, they are arguably more electorally consequential than most of those we have canvassed - for example welfare, food stamps and government aid to minorities. On these issues, Republicans, whatever their level of ideological awareness, will be of one mind: government spending on each should be cut. But how do Democrats react, and why?

Redistributive policies turn on the status quo: more should be done than is currently being done, or less than is being done or about the same as is being done. Championing more government spending on welfare is a bridge too far for most Democrats, while supporting cuts to welfare equates to defecting. In these circumstances, standing by the program as it is counts as defending it. Thus the status quo serves as a focal point, even for ideologically aware Democrats.

Table 2 reports mean support scores for Democratic and Republican identifiers, again centered on 0.5 and separated by two levels of ideological awareness, on three issues that are 
тав Le 2 Spending Preferences on Democrats' Uphill Issues

\begin{tabular}{lccccc}
\hline \hline & \multicolumn{2}{c}{ Democrats } & & \multicolumn{2}{c}{ Republicans } \\
\cline { 2 - 3 } \cline { 5 - 6 } & Low & High & & Low & High \\
\hline Welfare & 0.45 & 0.47 & 0.23 & 0.13 \\
& $(0.01)$ & $(0.01)$ & $(0.02)$ & $(0.01)$ \\
Aid to Blacks & 0.45 & 0.47 & 0.23 & 0.16 \\
& $(0.01)$ & $(0.01)$ & $0.01)$ & $(0.01)$ \\
Food Stamps & 0.44 & 0.51 & 0.37 & 0.29 \\
& $(0.02)$ & $(0.02)$ & $(0.03)$ & $(0.02)$
\end{tabular}

easy for Republicans and hard for Democrats. ${ }^{31}$ Just so far as Democrats are of one mind whatever their level of ideological awareness on issues that are easy for them, so, too, are Republicans on issues that are easy for them. As the two columns on the right make plain, whatever their level of awareness, Republicans are overwhelmingly in favor of cutting spending for welfare, aid to blacks and food stamps.

Just as the status quo serves as a focal point for social welfare issues that are hard for Democrats, they should coordinate with keeping spending about the same. Table 2 shows that this is, unsurprisingly, true for Democrats who score low on ideological awareness. For welfare, aid to blacks and food stamps, their mean support level, on a 0 to 1 scale, is 0.44 . The status quo, perhaps more surprisingly, is also a coordination point for Democrats who score high on ideological awareness $(0.47,0.47$ and 0.51 for welfare, aid to blacks and food stamps, respectively).

\section{Uphill Issues for Democrats: Partisan vs. Ideological/Policy Appeals}

We have seen that Democrats will support keeping spending about the same for policies like welfare. But if their party wants to rally them in support of a more liberal stand, even if only briefly, how can it do so? Previous research suggests that party-centered - rather than ideologycentered - appeals are one mechanism. ${ }^{32}$ The Ideological vs. Partisan Signals experiment tests this hypothesis ${ }^{33}$ focusing on whether 'the federal government should make every effort to ensure that everybody has a good standard of living' or 'each individual has a responsibility to get ahead on their own'. ${ }^{34}$ These alternatives, bringing out the tension between the values of policy liberalism and the core value of individual responsibility, present Democrats with a

31 Preferences on welfare and aid to minorities come from the 2012 ANES, in which they are labeled fedspend_welfare and aidblack_self, respectively, while food stamp preferences come from the 2000 ANES (labeled V000679), which was the last time the question was asked.

${ }^{32}$ In manipulating partisan and ideological cues, we follow the lead of pioneering studies, among them Kam (2005) and Rahn (1993). For us, Goren, Federico, and Kittilson (2009) is an especially significant exemplar, since they pick out sorted Democrats and Republicans for analysis. Their work, however, is focused on the effect of partisan cues on the expression of political values.

33 All survey experiments were custom designed and carried out on representative samples. The experiment is based on a survey of a representative sample of Californians, with respondents selected by Random Digit Dialing (RDD), carried out by the Survey Research Center of the University of California $(n=1,050)$.

${ }^{34}$ Participants responded on a four-point scale in which they indicated whether they were closer to one side or another. Scores on the test item range from 0 to 1 : the higher the score, the more liberal the position on the government jobs issue; the lower the score, the more conservative. 
TA B LE 3 Ideological vs. Partisan Signals Experiment

\begin{tabular}{lcc}
\hline \hline & \multicolumn{2}{c}{ Support for government jobs } \\
\cline { 2 - 3 } & Democrats vs. Republicans & Liberals vs. Conservatives \\
\hline Non-sorted & 0.76 & 0.54 \\
Democrats & $(0.04)$ & $(0.05)$ \\
Republicans & 0.15 & 0.22 \\
& $(0.06)$ & $(0.05)$ \\
Sorted & 0.94 & 0.84 \\
Democrats & $(0.03)$ & $(0.04)$ \\
Republicans & 0.09 & 0.08 \\
& $(0.03)$ & $(0.02)$ \\
\hline \hline
\end{tabular}

harder policy choice than Republicans. The experiment focuses on the comparative efficacy of ideological and partisan cues. In one condition the question begins: 'Democrats feel that [...] Republicans feel that'; in the other condition, the question begins: 'Liberals feel that [...] Conservatives feel that'.

Table 3 presents mean levels of responsiveness to partisan and ideological signals by party identification and their level of ideological sophistication, this time indexed by whether or not they were sorted. The second and fourth rows of Table 3 illustrate that partisan and ideological signals are synonymous for both non-sorted and sorted Republicans, or close enough to make no substantive difference. Non-sorted Republicans are strongly opposed to the policy regardless of the label, and the arithmetic difference of 0.07 points between the two conditions is statistically insignificant $(\mathrm{t}(55)=0.79$, ns). For sorted Republicans, the label makes no difference whatsoever, with a mean level of support of about 0.09 in both conditions $(\mathrm{t}(131)=0.12, \mathrm{~ns})$.

Ideological and partisan cues are not synonymous for non-sorted Democrats, though. When policy positions have party labels, their mean score is 0.76 ; when they have ideological labels, it is only $0.54(\mathrm{t}(110)=2.87, \mathrm{p}<0.01)$. Non-sorted Democrats are markedly more likely to rally to their party's side in response to party labels than to ideological signals. By contrast, sorted Democrats strongly favor their party's policy when it is party branded (0.94), and nearly as strongly when it is ideologically branded $(0.84 ; \mathrm{t}(130)=1.87, \mathrm{p}=0.06)$. Thus ideologically aware Democrats - indexed by whether they are sorted ${ }^{35}$ - resemble ideologically aware Republicans. The difference between the two parties is a function of the asymmetry between them in ideological awareness.

But it can be argued that these results are not dispositive. Rather, they show reactions to labels. The 'liberal' label, these (and many other) results indicate, does not have the same appeal as the 'conservative' label. But a label is only a label. Perhaps Democrats appear to rely more on partisan than programmatic appeals, not because they are less responsive than Republicans to the substance of the matter, but because they are not as excited by the wrapping it came in. The label 'liberal', after all, is less popular among Democrats as well as Republicans. ${ }^{36}$ What is

35 Sorting is the only measure of ideological awareness available in this study.

36 Mean thermometer scores in the 2004 ANES are 0.64 for Democrats for 'liberal', compared to 0.73 for Republicans for 'conservative' (see also Ellis and Stimson 2012). 


\begin{tabular}{lcccc}
\hline \hline & \multicolumn{2}{c}{ Support food stamps } \\
\cline { 2 - 5 } & $\begin{array}{c}\text { Parties and } \\
\text { arguments }\end{array}$ & $\begin{array}{c}\text { Parties without } \\
\text { arguments }\end{array}$ & $\begin{array}{c}\text { Arguments without } \\
\text { parties }\end{array}$ & $\begin{array}{c}\text { No parties, no } \\
\text { arguments }\end{array}$ \\
\hline Non-sorted & & & & \\
Democrats & 0.60 & 0.58 & 0.42 & 0.38 \\
Republicans & $(0.09)$ & $(0.09)$ & $(0.09)$ & $(0.07)$ \\
Sorted & 0.20 & 0.50 & 0.07 & 0.45 \\
Democrats & $(0.09)$ & $(0.17)$ & $(0.05)$ & $(0.19)$ \\
Republicans & 0.75 & 0.72 & 0.69 & 0.48 \\
& $(0.08)$ & $(0.07)$ & $0.07)$ & $(0.06)$ \\
& 0.13 & 0.12 & $(0.04)$ & 0.17 \\
\hline \hline
\end{tabular}

more, a number of studies have demonstrated that both ideological and party labels can move supporters every which way. ${ }^{37}$ It is perfectly possible, then, that Democrats may be as likely as Republicans to respond to the motivating idea behind social welfare policies.

To put this possibility to the test, the Policy Argument vs. Party Label experiment was carried out on a nationally representative online sample. ${ }^{38}$ The experiment is built around four conditions: (1) policy arguments (but not party labels) are supplied; (2) party labels (but not policy arguments) are provided; (3) both party labels and policy arguments are supplied; and (4) in the control condition, neither party labels nor policy arguments are provided (see the Appendix for item wording). Note that the social welfare issue, food stamps, is one on which Democrats face headwinds.

Table 4 shows the levels of support for increased spending on food stamps in the four experimental conditions: the higher the score, the higher the level of support for coupons that can be exchanged for food; the lower the score, the lower the level of support for food stamps. Again, policy preferences are calculated conditional on whether or not the partisan also shares the party's ideology. Without partisan labels, non-sorted Democrats tend to be on the wrong side of the issue. When non-sorted Democrats receive the party label, they are slightly in favor of food stamps ( 0.60 and 0.58 in the parties and arguments condition and parties without arguments condition, respectively). Without the label, they tend to be against them ( 0.42 and 0.38 in the arguments without parties condition and no parties, no arguments condition, respectively; the difference between the first two conditions and the second two conditions was significant, $\mathrm{t}(108)=2.37, \mathrm{p}<0.05)$. However, sorted Democrats need either a label or an argument to be in favor of food stamps; otherwise, they are opposed to the policy (the difference between the first three conditions and the last was significant, $\mathrm{t}(124)=3.08, \mathrm{p}<0.01)$.

37 Malka and Lelkes (2010) were able to move liberals and conservatives on a non-ideological issue to demonstrate that some view ideological groups as a social group. Our results do not exclude this possibility, but the next experiment rules out this mechanism in this study.

38 The Party Label vs. Policy Argument experiment was carried out by the Time-sharing Experiments in the Social Sciences (TESS) program. In December and January 2003-04, TESS contracted Knowledge Networks to administer the experiment to its nationally representative panel $(n=2,015)$, recruited through list-assisted RDD sampling. The panel recruitment response rate (based on AAPOR RR3) was 39 per cent. 
The reaction of Republicans could not be more different from that of Democrats. The non-sorted Republican takes a conservative position when he or she receives the argument $(0.20$ and 0.07 in the parties and arguments and arguments without parties conditions, respectively, $\mathrm{t}(20)=1.23$, ns), but prefers the status quo without an argument (0.50 and 0.45 in the parties without arguments and no parties, no arguments condition, respectively, $\mathrm{t}(12)=0.22$, ns; the difference between the no arguments and arguments conditions was significant, $t(34)=2.94$, $\mathrm{p}<0.01$ ). For the sorted Republican, preferences are approximately the same across conditions, ranging from 0.12 in the arguments without parties condition to 0.22 in the parties without arguments condition (the difference between these two conditions was not significant, $\mathrm{t}(116)=1.64, \mathrm{~ns})$. In a word, for sorted Republicans, party labels are superfluous. So, too, are policy arguments. A tough issue for Democrats is an easy issue for ideologically aware Republicans. They have no need of signals: they have internalized what goes with what, and why.

\section{Competing Hypotheses}

Skocpol and others argue that the political constituency willing to pay for policies that benefit particular groups rather than society as a whole is limited in size, ${ }^{39}$ and is almost certain to shrink as programs inevitably fail to fully achieve their ambitiously advertised goals.

The principle of benefits being awarded because they have been earned (rather than because they happen to be needed or wanted) goes to the core of the conservative temperament. One may hypothesize that this principle gives Republicans who identify with their party's ideological program a heuristic principle with which to oppose redistributive policies. There is a plausible competing hypothesis, however. Conservative positions on social welfare issues characteristically consist of opposition to increased government spending and, often, support for reduced government spending. Conservative positions can thus be fiscally self-serving. Republicans may maintain their bloc opposition to increases to scope-of-government services not for ideological reasons, but out of a concern for their pocketbooks. Self-interest is thus an eminently credible mechanism underpinning opposition to increased government spending for Republicans in particular, since they tend to be better off than Democrats. ${ }^{40}$

To arbitrate the merits of these two lines of reasoning - self-interest and policy particularism - the Taxes/Beneficiaries experiment was carried out. ${ }^{41}$ In September 2008, Knowledge Networks administered an online survey to a nationally representative sample of adults. In all, 60 per cent of the sample completed the interview $(n=1,501)$, yielding an American Association for Public Opinion Research R3 response rate of 7.3 per cent.

In one condition, the introduction took the standard form: 'Here is a list of some federal programs. For each one, please indicate whether you would like to see spending increased or decreased.' In the other condition, however, the introduction took this form:

The country is going through some tough times economically. Most experts agree that if federal government spending is increased, federal taxes will also have to be increased.

Of course experts are not always right and in any case the government has to provide basic services.

39 Skocpol 1991; Wilson 1980.

${ }^{40}$ E.g., Gelman 2009.

${ }^{41}$ The two lines of reasoning are not mutually exclusive. Republicans may oppose increased spending on social welfare policies both because more spending may entail higher taxes and because they see these policies as benefiting only a particular group. Nonetheless, our focus on ideology requires that policy particularism be overwhelmingly the decisive factor for them. 
TA В LE 5 The 'Tax Increase Experiment'

\begin{tabular}{lccc}
\hline \hline Policy & Condition & Democrats & Republicans \\
\hline Social Security & Control & 0.82 & 0.62 \\
& & $(0.02)$ & $(0.02)$ \\
& Tax Increase & 0.70 & 0.60 \\
Public Schools & & $(0.02)$ & $(0.02)$ \\
& Control & 0.86 & 0.61 \\
& Tax Increase & $(0.02)$ & $(0.03)$ \\
Child Care & & 0.75 & 0.54 \\
& Control & $(0.02)$ & $(0.02)$ \\
& & 0.68 & 0.43 \\
Poverty Program & Tax Increase & $(0.02)$ & $(0.03)$ \\
& & 0.67 & 0.41 \\
& Control & $(0.02)$ & $(0.02)$ \\
& & 0.77 & 0.40 \\
Welfare & Tax Increase & $(0.02)$ & $(0.03)$ \\
& & 0.68 & 0.42 \\
& Control & $(0.02)$ & $(0.02)$ \\
& & 0.50 & 0.26 \\
& Tax Increase & $(0.03)$ & $(0.02)$ \\
& & 0.40 & $(0.22$ \\
& & $(0.02)$ & \\
\hline \hline
\end{tabular}

But if more spending will mean higher taxes, please indicate whether you would like to see spending increased or decreased on the following federal programs.

After respondents expressed their positions on the different policies, they were asked who benefits most from each - particular groups, society at large or people like themselves. ${ }^{42}$

Consider first the Self-Interest Hypothesis. The intuition is that support for increased government spending on social welfare policies will decrease when citizens face the prospect of having to pay higher taxes. Table 5 presents levels of support for federal spending, by party, as a function of whether the likelihood of increases in spending entailed higher taxes or not. Positions of federal spending are recorded so that decrease is coded 0 , keep the same as 0.5 and increase as 1 .

Scrutinizing Table 5, one can see evidence of a retreat from liberal policies when having more means paying more. But the retreat is on the political left, not the right. Democrats give less support, for example, to increased spending for poverty programs and welfare when it means higher taxes $(0.09$ points, $\mathrm{t}(444)=2.87, \mathrm{p}<0.01$, and 0.10 points, $\mathrm{t}(444)=2.98$, $\mathrm{p}<0.01$, less support in the Tax Increase condition than the Control condition, respectively). For these policies, concern for their pocketbooks may not be surprising. What should be surprising, certainly it was surprising to us, is that Democrats also back off their support for popular policies like social security and public schools when spending more means paying more $(0.12$ points, $\mathrm{t}(444)=4.29 ; \mathrm{p}<0.01$, and 0.11 points, $\mathrm{t}(444)=4.09 ; \mathrm{p}<0.01$, less support in the Tax Increase condition than in the Control condition, respectively). By contrast, Republicans only balk a bit in the face of higher taxes for one program: public schools $(0.07$ points less support in the Tax Increase condition than in the Control condition, $t(426)=1.87$, $\mathrm{p}<0.10)$.

${ }^{42}$ Only a handful chose 'people like me' for any policy. It has therefore been eliminated from the analyses. 
(a) Percent seeing policy as particularistic, by party

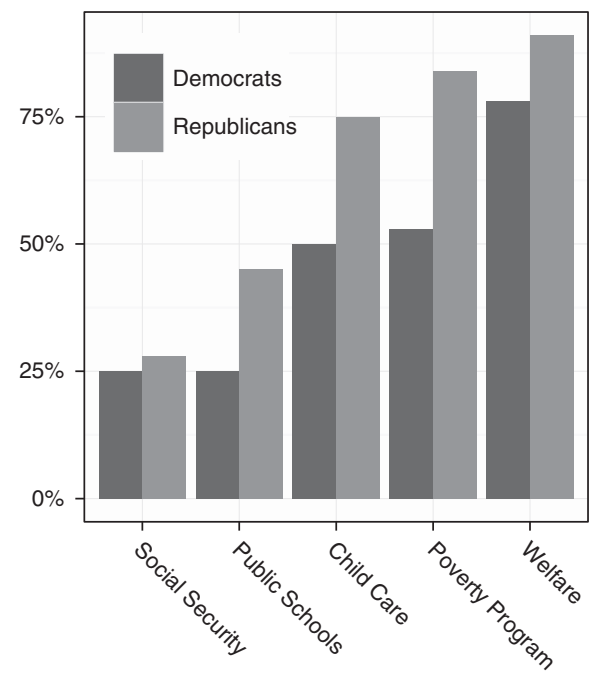

(b)

\begin{tabular}{|c|c|c|c|}
\hline Policy & Condition & Democrats & Republicans \\
\hline \multirow{4}{*}{ Social Security } & \multirow{2}{*}{ Particularistic } & 0.71 & 0.45 \\
\hline & & $(0.03)$ & $(0.03)$ \\
\hline & \multirow{2}{*}{ Society at large } & 0.76 & 0.69 \\
\hline & & $(0.02)$ & $(0.02)$ \\
\hline \multirow{4}{*}{ Public Schools } & \multirow{2}{*}{ Particularistic } & 0.65 & 0.41 \\
\hline & & $(0.03)$ & $(0.05)$ \\
\hline & \multirow{2}{*}{ Society at large } & 0.86 & 0.69 \\
\hline & & $(0.03)$ & $(0.04)$ \\
\hline \multirow{4}{*}{ Child Care } & \multirow{2}{*}{ Particularistic } & 0.55 & 0.32 \\
\hline & & $(0.02)$ & $(0.02)$ \\
\hline & \multirow{2}{*}{ Society at large } & 0.78 & 0.68 \\
\hline & & $(0.02)$ & $(0.04)$ \\
\hline \multirow{4}{*}{ Poverty Programs } & \multirow{2}{*}{ Particularistic } & 0.61 & 0.34 \\
\hline & & $(0.02)$ & $(0.02)$ \\
\hline & \multirow{2}{*}{ Society at large } & 0.86 & 0.73 \\
\hline & & $(0.02)$ & $(0.04)$ \\
\hline \multirow{4}{*}{ Welfare } & \multirow{2}{*}{ Particularistic } & 0.34 & 0.21 \\
\hline & & (0.02) & (0.01) \\
\hline & \multirow{2}{*}{ Society at large } & 0.64 & 0.57 \\
\hline & & $(0.03)$ & $(0.05)$ \\
\hline
\end{tabular}

Fig. 4. A test of the Particularism-Universalism Hypothesis

These details noted, the larger lesson to draw is that pocketbook considerations make a difference only at the margins, even for Democrats. Yes, they are consistently a little less enthusiastic about more spending if it means higher taxes. But the politically consequential point is that, even so, they overwhelmingly throw their weight behind more spending across the whole array of social welfare policies (with the exception only of welfare, which is hardly surprising). Self-interest is not irrelevant. But neither is it politically dispositive.

How, then, does our second hypothesis, Particularism-Universalism, fare? Figure 4 shows levels of support for social welfare policies, for Republicans and Democrats, depending on whether they see a policy as benefiting particular groups or society at large. For each issue, we show the percentage of Republicans and Democrats that sees the issue as particularistic (Panel A) as well as the mean level of support (Panel B). The policies are arrayed from least- to most-often judged to benefit a particular group. Roughly, both Republicans and Democrats are likely to judge a policy as particularistic in inverse proportion to the numbers that benefit from it. For our purposes, though, the pivotal point is that the two parties differ sharply on the likelihood of judging a policy to be particularistic. With the exception only of social security, Republicans consistently see a policy as benefiting a particular group to a larger degree than Democrats. Thus Republicans are roughly twice as likely as Democrats to see public schools as particularistic rather than universalistic (45 per cent vs. 25 per cent). Moreover, with the exception of archetypical universalistic policies (social security and public schools), Republicans are consensually agreed that policies on the social welfare agenda do not benefit society at large.

Consider, then, the policy that poses the highest hurdle for the Particularism hypothesis to clear: social security. More government spending is clearly the modal position. Not surprisingly, the 
overwhelming majority of Democrats who see it as universalistic strongly support increased spending (0.76). But the comparable majority of Republicans who agree it is universalistic are nearly as supportive (0.69); as, interestingly, are Democrats who see it as particularistic (0.71). Against this background, the position of Republicans who do not see social security as universalistic stands out starkly. They alone resist more spending by maintaining the status quo, if that (0.45).

Social security is the policy for which it is hardest for the Republican Party to garner allegiance - only a minority of its supporters views it as particularistic. For every other policy, a majority (or very close to it) of Republicans views it as particularistic and favors less spending, with the exception of public schools. Child care is an apt example. Three in every four Republicans see it as benefiting a particular group, and they come down clearly in favor of decreased spending (0.32).

All in all, then, the results very mildly support the Self-Interest Hypothesis, but strongly support the Particularism-Universalism conjecture. These results thus identify a particularly significant mechanism that helps Republicans maintain a remarkably unified front against widely appealing policies in the electorate as a whole.

\section{DISCUSSION}

Our argument may appear to conflict with the principal finding of Ellis and Stimson's ${ }^{43}$ seminal study of a tension between symbolic and operational ideology. They show that the symbolic label, conservative, is ambiguous: it may denote an ideological orientation, a religious commitment or neither; and by virtue of this ambiguity, the proportion that identifies themselves as conservative at the symbolic level but take liberal policy positions at the operational level 'conflicted conservatives', to use Ellis and Stimson's term - is strikingly large. This suggests or more precisely, can be taken to suggest - that there is less ideological coherence on the political right than on the left. By contrast, our most far-reaching result is that the partisan right is far more ideologically aware and oriented than the left: supporters of the party of conservatism have strikingly higher levels of ideological awareness and coherence than supporters of the party of liberalism.

The appearance of a contradiction is misleading. Two points in particular deserve emphasis. First, Ellis and Stimson focus on ideology at the symbolic level - specifically, identifying oneself as a liberal, conservative or moderate - by itself, in isolation from other considerations. We focus on ideological awareness, one indicator of which is ideological self-identification, which is taken into account if, but only if, it is consistent with party identification. ${ }^{44}$ Secondly, following a long tradition most prominently associated with Converse, ${ }^{45}$ the unit of analysis for Ellis and Stimson is the electorate as a whole. By contrast, following at least as long a tradition most prominently associated with Schattschneider, ${ }^{46}$ the unit of analysis for us is the party system. Our focus is the meaning of the term 'conservative' for Republicans and 'liberal' for Democrats, not for all voters or the mass public.

These two perspectives - one focusing on the electorate as a whole, the other on the portion of it that identifies with a political party - offer alternative frameworks for conceptualizing representation. Looking at the electorate as a whole frames the question of representation in

43 Ellis and Stimson 2012.

${ }^{44}$ In other words, we exclude conservatives who identify themselves as Democrats or moderates: it is these self-identified conservatives who fail to identify with the conservative party who are decisively liberal on measures of operational ideology. Data available upon request.

45 Converse 1964.

46 Schattschneider 1960. 
terms of the correspondence of policy outcomes and the preferences of the median voter. Looking at partisans in particular frames the question of representation in terms of the correspondence of policy outcomes and the preferences of the median party supporter. Our results show that at a strategic level, the interplay of the two perspectives brings out incentives that distinguish candidates competing under the banner of opposing parties.

Highlighting the asymmetry in ideological awareness between Republican and Democratic identifiers is only the first step in a broader research program. A next step is to identify the sources of this asymmetry. Our results exclude some obvious candidates. For example, it could well be argued that, because it is easier for a small group to achieve homogeneity than for a large group to do so, Republicans are more ideologically aware and coherent because they are a smaller group than Democrats. However, the difference in ideological awareness that is attributable to being a Republican rather than a Democrat is as large when the gap in the size of the two parties is very small as when it is very large (see Table 1). A second candidate explanation is social context. Republicans tend to have higher levels of education, socioeconomic status and political interest than Democrats. These, among other differences, may plausibly account for the higher levels of ideological awareness among Republicans than Democrats. We have tested this line of reasoning using various methods. The results of the matching analysis in Figure 2, and those of the regression analysis in Table A1, show that the Republican advantage in ideological awareness is not a spurious byproduct of a wide array of socio-demographic and political factors. ${ }^{47} \mathrm{~A}$ third candidate explanation is cross-agenda buttressing. According to this line of reasoning, Republicans tend to be able to hold their ground in opposition to social welfare issues that are widely popular in the electorate not because of their level of ideological sophistication per se, but because of their level of commitment to their party's positions on the second major policy agenda in American electoral politics: social values. The results of a variety of tests, including factor analysis, challenge this line of reasoning. Using the usual standards, the positions of the two policy agendas are orthogonal within parties as well as between them. ${ }^{48}$

Ruling out what plausibly could have accounted for partisan asymmetry in ideological awareness is not an insignificant step. But the next step is to identify what does account for ideological asymmetry between the parties. A body of work demonstrating the greater ideological and organizational coherence of the Republican Party at the elite level ${ }^{49}$ points to a top-down explanation of Republicans' greater ideological awareness and orientation at the level of identifiers. A separate body of work focused on personality-grounded bases of liberalism-conservatism points to a bottom-up explanation. ${ }^{50}$ The two lines of work are not mutually exclusive, it should be emphasized, as a growing body of research personality-context interactions makes plain. ${ }^{51}$

\section{CONCLUSION}

The objective of this study has been to establish whether there is a profound partisan asymmetry in ideological awareness. Some broader implications therefore deserve mention. To begin, a striking feature of the American party system is its tendency toward equilibrium. As Stokes

\footnotetext{
47 The analysis of Table 2 is directed at the issue of spuriousness. In the real world of politics, the Republican advantage in ideological awareness is the sum of Republican advantage and factors (e.g., higher education) that are correlated with Republican identification.

48 Results available upon request.

49 E.g., Feldman and Zaller 1992; Freeman 1986; Heaney 2012.

50 E.g., Jost et al. 2003; Mondak 2010; Tetlock 1983.

51 E.g., Gerber et al. 2010; Mondak et al. 2010.
} 
and Iversen ${ }^{52}$ observed a half-century ago, despite dramatic ups and downs in party fortunes over the short term, a longer-term view shows that party competition seldom strays outside a fairly narrow competitive range. What accounts for this equilibrium?

Superficially, it is a bit of a mystery. The social welfare agenda has been the most electorally consequential cleavage in American politics over the last eight decades at least, and has become more, not less, consequential over the last several decades. ${ }^{53}$ But the liberal position on the social welfare agenda has dominated the conservative position, brief periods aside, and usually by a wide margin. How has the Republican Party maintained itself when the winds of policy fortune have blown against it so strongly, and for so long?

Our results point to an equilibrium-reinforcing mechanism. If the Democratic Party has had the advantage of markedly more popular policies on the primary agenda of American politics, the Republican Party has had the advantage of more ideologically aware adherents, and ideological awareness has, our results show, adhesive power. Ideologically aware and oriented Republicans stick with their party's programmatic commitment to cutting social welfare benefits on the bulk of policies that are broadly popular in the electorate and seem to be appealing to them, and they do so in large measure by virtue of their being ideologically oriented and aware.

To make ideological awareness a centerpiece of a study of public opinion may seem to be waving a red flag. The conventional view, after all, is that citizens are 'innocent of ideology'. ${ }^{54}$ In fact, our results complement rather than contradict the conventional wisdom. For one thing, this is a study of partisans, not of the mass public as an undifferentiated whole. For another, having a political ideology has typically been equated with having a political cosmology: that is, an interconnected system of abstract beliefs that lends insight into the dynamics of politics and the economy. By contrast, we have set out a down-to-earth view of what it means to be ideologically aware and oriented: to identify with the same political outlook that one's party is identified with, to know the ideological positions of the parties relative to one another, and to largely ground one's attachment to one's party in ideological and policy concerns.

Both parties have identified themselves with a consistent view of the scope of government on social welfare issues. In turn, substantial numbers in both parties are prepared, able and often discuss - indeed, argue about - the direction that government policy should take. Most generally, then, our results point to the utility of distinguishing between studies on ideology in the electorate as a whole and research on the levels of ideological awareness among political partisans. Ideological considerations take on life in the clash of partisan politics, and our results suggest that asymmetries in ideological awareness between Republicans and Democrats are a telling feature of the clash between the parties.

\section{REFERENCES}

Abramowitz, A.I., and K.L. Saunders. 1998. Ideological Realignment in the U.S. Electorate. The Journal of Politics 60 (3):634-52.

Ansolabehere, S., J.M. Snyder Jr, and C. Stewart III. 2001. Candidate Positioning in US House Elections. American Journal of Political Science 45 (1):136-59.

Bartels, L.M. 1996. Uninformed Votes: Information Effects in Presidential Elections. American Journal of Political Science 40 (1):194-230.

52 Stokes and Iverson 1962.

53 Bartels 2000.

54 Kinder 1983, 390-1. 
—. 2000. Partisanship and Voting Behavior, 1952-1996. American Journal of Political Science 44 (1):35-50.

Brown, R.D. 1995. Party Cleavages and Welfare Effort in the American States. American Political Science Review 89:23-33.

Bullock, J.G. 2011. Elite Influence on Public Opinion in an Informed Electorate. American Political Science Review 105 (3):496-515.

Carmines, E.G., and J.A. Stimson. 1990. Issue Evolution: The Race and the Transformation of American Politics. Princeton, NJ: Princeton University Press.

Conover, P.J., and S. Feldman. 1981. The Origins and Meaning of Liberal/Conservative SelfIdentifications. American Journal of Political Science 25 (4):617-45.

Converse, P.E. 1964. The Nature of Belief Systems in Mass Publics. In Ideology and Discontent, edited by D.E. Apter. 206-61. New York: Free Press.

Dalton, R.J., P.A. Beck, and R. Huckfeldt. 1998. Partisan Cues and the Media: Information Flows in the 1992 Presidential Election. American Political Science Review 92 (1):111-26.

Ellis, C., and J.A. Stimson. 2009. Symbolic Ideology in the American Electorate. Electoral Studies 28 (3):388-402.

- 2011. Pathways to Conservative Identification. In Facing the Challenge of Democracy: Explorations in the Analysis of Public Opinion and Political Participation, edited by P.M. Sniderman and B. Highton, 120-52. Princeton, NJ: Princeton University Press.

- 2012. Ideology in America. New York: Cambridge University Press.

Feldman, S., and J. Zaller. 1992. The Political Culture of Ambivalence: Ideological Responses to the Welfare State. American Journal of Political Science 36 (1):268-307.

Freeman, J. 1986. The Political Culture of the Democratic and Republican Parties. Political Science Quarterly 101 (3):327-56.

Gelman, A. 2009. Red State, Blue State, Rich State, Poor State: Why Americans Vote the Way They Do. Princeton, NJ: Princeton University Press.

Gerber, A.S., G.A. Huber, D. Doherty, C.M. Dowling, and S.E. Ha. 2010. Personality and Political Attitudes: Relationships across Issue Domains and Political Contexts. American Political Science Review 104 (1):111-33.

Goren, P., C.M. Federico, and M.C. Kittilson. 2009. Source Cues, Partisan Identities, and Political Value Expression. American Journal of Political Science 53 (4):805-20.

Green, D.P., B. Palmquist, and E. Schickler. 2002. Partisan Hearts and Minds: Political Parties and the Social Identities of Voters. New Haven, CT: Yale University Press.

Heaney, M.T., S.E. Masket, J.M. Miller, and D.Z. Strolovitch. 2012. Polarized Networks: The Organizational Affiliations of National Party Convention Delegates. American Behavioral Scientist 56 (12):1654-76.

Iacus, S.M., G. King, and G. Porro. 2012. Causal Inference Without Balance Checking: Coarsened Exact Matching. Political Analysis 20 (1):1-24.

Jost, J.T., J. Glaser, A.W. Kruglanski, and F.J. Sulloway. 2003. Political Conservatism as Motivated Social Cognition. Psychological Bulletin 129 (3):339.

Kahneman, D. 2011. Thinking, Fast and Slow. New York: Farrar, Straus and Giroux.

Kam, C.D. 2005. Who Toes the Party Line? Cues, Values, and Individual Differences. Political Behavior 27 (2):163-82.

Kinder, D.R. 1983. Diversity and Complexity in American Public Opinion. In Political Science. The State of the Discipline, edited by A. Finifter, 391-401. Washington: APSA.

2003. Belief Systems after Converse. In Electoral Democracy, edited by M. MacKuen and G. Rabinowitz, 13-47. Ann Arbor: University of Michigan Press.

Levendusky, M. 2009. The Partisan Sort: How Liberals Became Democrats and Conservatives Became Republicans. Chicago, IL: University of Chicago Press.

Malka, A., and Y. Lelkes. 2010. More Than Ideology: Conservative-Liberal Identity and Receptivity to Political Cues. Social Justice Research 23 (2-3):156-88.

Mondak, J.J. 1993. Source Cues and Policy Approval: The Cognitive Dynamics of Public Support for the Reagan Agenda. American Journal of Political Science 37 (1):186-212. 
- 2010. Personality and the Foundations of Political Behavior. New York: Cambridge University Press.

Mondak, J.J., M.V. Hibbing, D. Canache, M.A. Seligson, and M.R. Anderson. 2010. Personality and Civic Engagement: An Integrative Framework for the Study of Trait Effects on Political Behavior. American Political Science Review 104 (1):85-110.

Petersen, M.B. 2012. Social Welfare as Small-Scale Help: Evolutionary Psychology and the Deservingness Heuristic. American Journal of Political Science 56 (1):1-16.

Petersen, M.B., R. Slothuus, R. Stubager, and L. Togeby. 2011. Deservingness Versus Values in Public Opinion on Welfare: The Automaticity of the Deservingness Heuristic. European Journal of Political Research 50 (1):24-52.

Rahn, W.M. 1993. The Role of Partisan Stereotypes in Information Processing About Political Candidates. American Journal of Political Science 37 (2):472-96.

Schattschneider, E.E. 1960. The Semi-Sovereign People: A Realist's View of Democracy in America. New York: Holt, Rinehart \& Winston.

Skocpol, Theda. 1991. Targeting Within Universalism: Politically Viable Policies to Combat Poverty in the United States. In The Urban Underclass, edited by C. Jencks and P.E. Peterson, 411-36. Washington, DC: The Brookings Institution.

Squire, P., and E.R.A.N. Smith. 1988. The Effect of Partisan Information on Voters in Nonpartisan Elections. Journal of Politics 50 (1):169-79.

Stimson, J.A. 1991. Public Opinion in America: Moods, Cycles, and Swings. Boulder, CO: Westview Press.

- 2004. Tides of Consent: How Public Opinion Shapes American Politics. New York: Cambridge University Press.

Stokes, D.E., and G.R. Iversen. 1962. On the Existence of Forces Restoring Party Competition. Public Opinion Quarterly 26 (2):159-71.

Wilson, W.J. 2012. The Declining Significance of Race: Blacks and Changing American Institutions. Chicago, IL: University of Chicago Press.

Zaller, J. 1986. Analysis of Information Items in the 1985 NES Pilot Study, Ann Arbor, MI: National Election Pilot Study Report.

1992. The Nature and Origins of Mass Opinion. New York: Cambridge University Press. 